\title{
PERAN FUNGSI EKSEKUTIF SISWA SMP DALAM MENYELESAIKAN SOAL CERITA DITINJAU DARI KEMAMPUAN MATEMATIKA
}

\author{
Cicik Fauziyah \\ Pendidikan Matematika, Fakultas Pendidikan Matematika dan Ilmu Pengetahuan Alam, Universitas Negeri Surabaya \\ E-mail: cicikfauziyah@mhs.unesa.ac.id
}

\begin{abstract}
Abstrak
Matematika merupakan subjek yang memiliki pengaruh penting dalam kehidupan sehari-hari. Sehingga matematika dijadikan subjek pembelajaran pada hampir setiap jenjang pendidikan. Namun banyak orang yang mengeluh mengalami kesulitan dalam pengerjaan soal-soal matematika. Salah satu faktor yang mempengaruhi seseorang dalam menyelesaikan persoalan matematika adalah fungsi eksekutif. Penelitian ini akan melakukan penelitian untuk menjabarkan peran dari fungsi eksekutif siswa dalam pembelajaran matematika. Metode yang digunakan dalam adalah penelitian deskriptif kualitatif. Peneliti akan melakukan eksplorasi terhadap peran fungsi eksekutif siswa SMP dalam menyelesaikan soal cerita dengan subjek tiga siswa kelas VIII dari SMP Negeri 5 Surabaya. Teknik pengumpulan data yang digunakan berupa tes dan wawancara. Hasil penelitian menunjukkan tingkat kemampuan matematika memberikan peran terhadap kemampuan siswa dalam menyelesaikan soal cerita. Terdapat indikasi bahwa semakin tinggi tingkat kemampuan matematika, maka fungsi eksekutif yang dimiliki semakin tinggi dan siswa akan menyelesaikan bentuk soal cerita dengan lebih baik. Kesimpulan dalam penelitian ini adalah terdapat peran penting dari fungsi eksekutif terhadap kemampuan siswa dalam menyelesaikan soal cerita dalam matematika.
\end{abstract}

Kata Kunci: matematika, soal cerita, kemampuan matematika, fungsi eksekutif

\section{Abstract}

Mathematics is a subject that has an important influence in every daily life. So that mathematics becomes the subject of learning at almost every level of education. However, many people complain that they have difficulty working on math problems. One of the factors that influence someone in solving math problems is the executive function. This study will conduct research to describe the role of the executive function of students in learning mathematics. The method used in this is descriptive qualitative research. Researchers will explore the role of junior high school students' executive function in solving story problems with the subject of three eighth grade students from 5 Junior High School of Surabaya. Data collection techniques used were tests and interviews. The results showed that the level of mathematical ability played a role in students' ability to solve story problems. There is an indication that the higher the level of mathematical ability, the higher the executive function they have and the students will solve the form of the story problem better. The conclusion in this study is that there is an important role of the executive function on students' ability to solve story problems in mathematics.

Keywords: mathematics, word problems, math skills, executive function

\section{PENDAHULUAN}

Matematika merupakan ilmu pengetahuan yang memiliki peranan penting dalam berbagai aspek kehidupan. Banyak permasalahan dan aktivitas kita dalam kehidupan sehari-hari yang diselesaikan dengan menggunakan ilmu matematika seperti menghitung, mengukur, dan lain-lain. Matematika diajarkan dalam seluruh jenjang pendidikan formal, mulai dari pendidikan dasar hingga pendidikan tinggi. Hal ini menunjukkan bahwa matematika memiliki peran penting dalam ilmu dalam pendidikan di Indonesia. Dengan adanya pembelajaran matematika di sekolah, diharapkan dapat melatih siswa dalam berpikir logis, kritis, kreatif, serta dapat memecahkan masalah baik dalam mata pelajaran sekolah, dunia kerja, maupun dalam kehidupan sehari-hari.

Matematika memiliki tujuan seperti tertuang pada Permendikbud Nomor 58 Tahun 2014 yaitu agar siswa mampu: (1) memahami konsep matematika, (2) menyelesaikan masalah, (3) menggunakan penalaran matematis, (4) mengkomunikasikan masalah secara sistematis dan (5) memiliki sikap dan perilaku yang sesuai dengan nilai dan matematika. Dapat dilihat bahwa matematika diajarkan karena mampu mengembangkan kemampuan siswa dalam menyelesaikan masalah. Siswa diharapkan mampu untuk berpikir sistematis, logis dan kritis dalam memberikan gagasan atau ide dalam menyelesaikan masalah. Permasalahan matematika dapat 
diaplikasikan di sekolah misalnya dalam bentuk soal cerita. Beberapa bentuk soal cerita dapat digunakan pada jenjang pendidikan tingkat Sekolah Dasar (Amir, 2015; Rahmania \& Rahmawati, 2016; Ariani \& Kenedi, 2018), jenjang pendidikan tingkat Sekolah Menengah (Farida, 2015; Novferma, 2016; Kahar \& Layn, 2017) bahkan dipergunakan untuk soal ujian masuk perguruan tinggi (Mulyani \& Muhtadi, 2019) dan tes penerimaan pegawai.

Pada penelitian yang dilakukan oleh Ansori (2015) disebutkan bahwa banyak ditemukan peserta didik mengalami kesulitan dalam memahami soal cerita yang di berikan. Hal ini disebabkan oleh beberapa faktor yaitu kebahasaan, tahap transformasi, keterampilan proses, dan tahap pengkodean. Permasalahan terkait kebahasaan contohnya adalah siswa mengalami kesulitan dalam memahami makna dan maksud dari kata kunci pada soal cerita. Kesulitan pada tahap transformasi misalnya ditemui pada penggunaan model barisan aritmetika dan geometri pada soal cerita. Selanjutnya bentuk kesulitan pada tahap keterampilan proses misalnya adalah kesulitan pemahaman konsep substitusi dan pemfaktoran pada persamaan kuadrat. Bentuk kesulitan pada tahap pengkodean misalnya siswa sulit dalam menafsirkan jawaban yang diperolehnya ke dalam masalah yang diberikan.

Faktor yang dipaparkan oleh Ansori (2015) termasuk ke dalam kelompok keterampilan kognitif. Keterampilan kognitif seseorang memiliki hubungan erat dalam mengolah informasi penyelesaian masalah. Domain keterampilan tersebut disebut dengan fungsi eksekutif. Fungsi eksekutif merupakan suatu istilah yang diberikan pada sekelompok proses yang mengarahkan individu untuk merespon lingkungan secara fleksibel dan berhubungan dengan pemikiran dan aksi yang berpusat pada suatu tujuan. Fungsi eksekutif membentuk basis kemampuan seperti kemampuan penyelesaian masalah dan pemikiran yang fleksibel (Cragg \& Gilmore, 2014).

Terdapat tiga tipe fungsi eksekutif yang telah teridentifikasi yaitu: (1) proses memonitor dan memanipulasi informasi pada fikiran (memori kerja), (2) proses seseorang menghalangi informasi menyimpang dan respon yang tidak diinginkan (inhibisi) dan (3) pemikiran yang fleksibel (shifting). Roditi dan Steinberg (2007) menambahkan dua fungsi eksekutif yaitu (4) prioritizing dan (5) checking. Seluruh tipe dalam fungsi eksekutif ini memiliki peran dalam penyelesaian soal cerita dalam matematika. Peneliti akan menggunakan lima tipe fungsi eksekutif ini sebagai indikator untuk melihat kemampuan siswa dalam menyelesaikan soal cerita.

Penelitian yang dilakukan oleh Gilmore dan Cragg (2014) mengenai peran fungsi eksekutif di berbagai aspek matematika menunjukkan bahwa fungsi eksekutif sangat berperan penting dalam kemampuan siswa di dalam pembelajaran matematika. Peran penting tersebut terlihat dari kemampuan siswa dalam menyelesaikan soal cerita dengan menganalisis informasi yang diperoleh, mengingat dan menerapkan informasi, fakta, konsep, prosedur dan strategi yang didapat sebelumnya (working memory), memperkirakan dan menentukan waktu yang dibutuhkan (organization), merencanakan langkah-langkah penyelesaian (planning), mengeliminasi informasi yang tidak dibutuhkan (inhibition), menentukan strategi pemecahan masalah yang tepat (shifting), serta membuat kesimpulan mengenai soal yang diberikan (concept formation).

Sejalan dengan pendapat Gilmore dan Cragg (2014), Raghubar, Barnes, dan Hect (2010: 113) juga menyatakan bahwa, "Working memory is involved in mathematical performance whether it single or multi-digit arithmetic." Dari pernyataan tersebut dapat dikatakan bahwa working memory berpengaruh terhadap kemampuan matematika dalam menyelesaikan soal perhitungan yang mudah maupun sulit. Selain itu peran lainnya juga dapat dilihat dari proses inhibition and shifting yang berperan dalam aktivitas siswa untuk mengeliminasi informasi dan pengetahuan yang tidak dibutuhkan sehingga dapat menentukan metode dan stategi pemecahan masalah yang sesuai dengan soal yang diberikan.

Tidak hanya itu, Kulman \& Daley juga mengungkapkan bahwa peran fungsi eksekutif dalam matematika merupakan salah satu faktor penentu utama keberhasilan siswa dalam menyelesaikan permasalahan matematika yang kompleks (Kulman \& Daley, 2016). Dengan demikian jelaslah bahwa peran fungsi eksekutif sangat dibutuhkan dalam kemampuan siswa untuk menyelesaikan soal cerita.

Logsdon (2020) mengungkapkan bahwa setiap siswa memiliki fungsi eksekutif yang berbeda-beda yang dapat mempengaruhi kemampuan matematika siswa. Hal tersebut terlihat pada saat menyelesaikan soal cerita, siswa yang memiliki masalah fungsi eksekutif akan kesulitan dalam mengatur dan menyelesaikan soal dengan tepat waktu, kesulitan membuat perencanaan penyelesaian, kesulitan memunculkan ide untuk menyelesaikan soal, kesulitan menyelesaikan masalah kompleks, dan kesulitan menggunakan informasi atau materi sebelumnya untuk memecahkan permasalahan baru (Team, 2020). Hal ini didukung oleh pendapat Kelly (2014) yang menyatakan bahwa, masalah fungsi eksekutif berdampak pada kemampuan matematika siswa, yaitu siswa akan kesulitan menerapkan konsep matematika baru, tergesa-gesa dalam menyelesaikan soal yang diberikan, serta kesulitan memberi jawaban langsung pada permasalahan matematika yang sederhana. Dengan demikian, siswa yang memiliki masalah fungsi eksekutif akan kesulitan mengingat dan menghubungkan soal satu dengan yang lain serta kesulitan memecahkan soal yang kompleks. Sehingga 
jelaslah bahwa fungsi eksekutif sangat berkaitan dengan kemampuan matematika siswa.

Dalam menyelesaikan soal cerita, langkah dan strategi yang digunakan siswa tidak sama antara siswa satu dengan siswa yang lain. Salah satu kemungkinan penyebabnya adalah perbedaan kemampuan matematika. Kemampuan matematika mempengaruhi proses berpikir siswa dalam menyelesaikan soal cerita, karena setiap siswa memiliki kemampuan matematika yang berbeda-beda. Kemampuan matematika siswa terdiri dari tiga kelompok, yaitu kemampuan matematika tinggi, kemampuan matematika sedang, dan kemampuan matematika rendah (Rofiki, 2013).

Adapun materi yang digunakan dalam penelitian ini adalah materi sistem persamaan linear dua variabel, karena materi tersebut sesuai sebagai penerapan fungsi eksekutif yang melatih beberapa keterampilan, seperti memungkinkan siswa untuk menganalisis informasi yang diperoleh, mengingat informasi dan strategi penyelesaian yang telah didapat untuk menyelesaikan soal yang diberikan (working memory), merencanakan langkahlangkah penyelesaian (planning), mengeliminasi informasi yang tidak dibutuhkan (inhibition), menentukan strategi pemecahan masalah yang tepat (shifting), memeriksa kembali langkah penyelesaian dan hasil yang diperoleh (checking), dan membuat kesimpulan mengenai soal yang diberikan, serta penerapan materi sistem persamaan linear dua variabel banyak dijumpai dalam kehidupan sehari-hari.

Berdasarkan penjelasan di atas, tujuan dari penelitian ini adalah untuk mendeskripsikan peran fungsi eksekutif siswa SMP dalam menyelesaikan soal cerita ditinjau dari kemampuan matematika.

\section{METODE PENELITIAN}

\section{Jenis Penelitian}

Penelitian ini dilakukan dengan menggunakan metode penelitian deskriptif kualitatif. Penggunaan metode penelitian deskriptif kualitatif karena peneliti ingin menggambarkan fenomena dan keadaan secara apa adanya, tanpa adanya perlakuan, perubahan, dan manipulasi terhadap variabel yang diteliti (Sukmadinata, 2011). Peneliti menggunakan metode deskriptif kualitatif karena peneliti ingin melakukan eksplorasi terhadap peran fungsi eksekutif siswa SMP dalam menyelesaikan soal cerita, jika ditinjau dari kemampuan matematika. mendeskripsikan peran fungsi eksekutif siswa SMP dalam menyelesaikan soal cerita ditinjau dari kemampuan matematika tinggi, sedang, dan rendah. Lebih lanjut, penelitian ini bersifat induktif dengan hasil yang lebih menekankan pada makna.

Penelitian ini memiliki rancangan penelitian sebagai berikut, langkah awal sebelum melakukan penelitian adalah menyusun instrumen penelitian yang akan digunakan. Selanjutnya peneliti melakukan Tes
Kemampuan Matematika (TKM) kepada siswa. TKM ini dilakukan untuk memperoleh pengelompokan kemampuan matematika siswa, yaitu kemampuan matematika tinggi, sedang, dan rendah. Hasil tes tulis matematika ini digunakan untuk menentukan subjek penelitian. Sekolah SMP Negeri 5 Surabaya dipilih peneliti sebagai lokasi penelitian dengan subjek yang digunakan dalam penelitian ini adalah siswa kelas VIII yang diikuti sebanyak 36 siswa. Siswa kelas VIII dipilih karena sudah mendapatkan pengajaran tentang materi sistem persamaan linear dua variabel, sehingga dianggap sudah mempunyai kemampuan untuk mengaplikasikan materi sistem persamaan linear dua variabel dalam menyelesaikan Tes Soal Cerita Matematika (TSCM) yang diberikan.

\section{Subjek Penelitian}

Subjek yang digunakan dalam penelitian ini adalah tiga siswa kelas VIII dari SMP Negeri 5 Surabaya yang memiliki kemampuan matematika rendah, sedang, dan tinggi. Tujuan penggunaan tiga subjek dalam penelitian ini adalah agar hasil penelitian lebih fokus dan mendalam. Siswa dipilih sesuai dengan kriteria yang ditentukan oleh peneliti.

Kriteria pertama yang digunakan dalam penentuan subjek adalah siswa dengan kemampuan komunikasi baik. Siswa yang mampu melakukan komunikasi dengan baik akan, baik dengan lisan maupun tulisan. Hal ini dikarenakan dalam penelitian ini akan dilakukan pengambilan data secara wawancara. Jadi kemampuan komunikasi yang baik diperlukan dalam penelitian ini. Kriteria kedua adalah siswa harus memiliki kemampuan matematika tinggi, sedang, dan rendah. Penentuan tingkat kemampuan matematika anak diperoleh melalui tes kemampuan matematika.

\section{Teknik Pengumpulan Data}

Terdapat dua teknik yang digunakan dalam penelitian ini, yaitu tes dan wawancara. Tes yang diberikan kepada subjek penelitian adalah Tes Kemampuan Matematika (TKM) dan Tes Soal Cerita Matematika (TSCM). Waktu yang digunakan untuk melaksanakan TKM adalah 40 menit. tujuannya untuk memetakan kemampuan matematika anak dalam satu kelas sebelum dilakukan reduksi data. Waktu yang digunakan untuk melaksanakan TSCM adalah 40 menit. Tujuan TSCM adalah untuk mengetahui kemampuan siswa dalam menyelesaikan soal cerita.

Wawancara dilakukan setelah subjek menyelesaikan TSCM. Wawancara dalam penelitian ini bersifat semi terstruktur yang berarti kalimat pertanyaan wawancara yang diajukan disesuaikan dengan kondisi subjek penelitian, tetapi makna dari permasalahan tersebut masih tetap ada. Wawancara dilakukan untuk memperoleh informasi/data terkait peran fungsi eksekutif siswa SMP dalam menyelesaikan soal cerita ditinjau dari kemampuan 
Matematika.

Data yang diperoleh dari hasil TSCM dan wawancara selanjutnya direduksi dengan menyesuaikan tujuan dari pelaksanaan TSCM dan wawancara. Hasil reduksi data selanjutnya disajikan dalam bentuk kumpulan data yang terorganisir. Data ini disusun berdasarkan indikator dalam proses penelitian untuk memudahkan penarikan kesimpulan. Selanjutnya dilakukan penarikan kesimpulan dari data yang telah dikumpulkan yaitu tentang kemampuan berpikir kritis siswa SMP dalam pembuktian matematika berdasarkan indikator berpikir kritis yang meliputi kategori klarifikasi, penilaian, inferensi dan strategi.

Tabel 1. Indikator Fungsi Eksekutif dalam Menyelesaikan Soal Cerita

\begin{tabular}{|c|c|l|}
\hline No. & $\begin{array}{c}\text { Proses Fungsi } \\
\text { Eksekutif }\end{array}$ & \multicolumn{1}{|c|}{ Indikator } \\
\hline 1. & Memory & $\begin{array}{l}\text { Mengingat pengetahuan yang } \\
\text { diperoleh (konsep dan strategi } \\
\text { penyelesaian) }\end{array}$ \\
\hline 2. & Organizing & $\begin{array}{l}\text { a. Mengorganisasi informasi } \\
\text { yang relevan dan tidak } \\
\text { relevan berdasarkan } \\
\text { pengetahuan yang diperoleh } \\
\text { b. Menuliskan apa yang } \\
\text { diketahui dan ditanya }\end{array}$ \\
\hline 3. & Shifting & $\begin{array}{l}\text { a. Merepresentasikan soal ke } \\
\text { dalam model matematika } \\
\text { b. Menentukan rencana } \\
\text { penyelesaian masalah }\end{array}$ \\
\hline 4. & Prioritizing & $\begin{array}{l}\text { Melaksanakan perencanaan } \\
\text { penyelesaian masalah yang } \\
\text { telah ditentukan secara } \\
\text { berurutan }\end{array}$ \\
\hline 5. & Checking & $\begin{array}{l}\text { Memeriksa kembali (konsep, } \\
\text { strategi penyelesaian, proses } \\
\text { pengerjaan, dan hasil yang } \\
\text { diperoleh) }\end{array}$ \\
\hline
\end{tabular}

Diadaptasi dari Roditi dan Steinberg (2007)

\section{Instrumen Penelitian}

Instrumen yang digunakan dalam pengambilan data di penelitian ini meliputi soal Tes Kemampuan Matematika (TKM), soal Tes Soal Cerita Matematika (TSCM), dan pedoman wawancara.

Instrumen TKM digunakan peneliti untuk mengetahui tingkat kemampuan matematika dari subjek penelitian. Subjek penelitian berasal dari seluruh kelas VIII di SMPN 5 Surabaya. Dari seluruh siswa kelas 8 tersebut direduksi dengan cara pengambilan data TKM siswa sehingga diperoleh siswa dengan TKM tertinggi, terendah, dan ratarata.
Instrumen TSCM digunakan untuk mengetahui peran fungsi eksekutif subjek penelitian dalam menyelesaikan soal cerita ditinjau dari kemampuan matematika. Materi yang digunakan dalam penelitian TSCM adalah sistem persamaan linear dua variabel berupa soal cerita yang kontekstual dan dapat diselesaikan. Adapun indikator yang digunakan untuk mengetahui peran fungsi eksekutif subjek penelitian dalam menyelesaikan soal cerita merujuk pada pendapat Roditi dan Steinberg (2007) seperti ditunjukkan pada Tabel 1.

\section{HASIL DAN PEMBAHASAN \\ Hasil Tes Kemampuan Matematika (TKM)}

TKM digunakan untuk mengetahui kemampuan matematika siswa. Materi yang digunakan dalam TKM adalah sistem persamaan linear tiga variabel. Pemilihan jenis materi ini berdasarkan materi yang telah diterima oleh siswa selama pembelajaran di sekolah. Sehingga peneliti tidak perlu memberikan penjelasan terlebih dahulu kepada siswa sebelum melaksanakan tes.

Berdasarkan hasil TKM, diperoleh nilai tertinggi dari siswa adalah 99 dan nilai terendah adalah 42. Kedua nilai ini digunakan sebagai acuan pemilihan siswa dengan TKM tinggi dan rendah. Untuk penentuan siswa yang memiliki TKM sedang, diambil data dari siswa dengan nilai TKM berada di rata-rata skor seluruh siswa. Diperoleh skor ratarata dari seluruh siswa adalah 71. Selanjutnya siswa dengan TKM rendah akan disebut dengan TKMR, siswa dengan TKM sedang akan disebut dengan TKMS, dan siswa dengan TKM tinggi akan disebut dengan TKMT.

\section{Hasil Tes Soal Cerita Matematika (TSCM) dan Wawancara}

Tes Soal Cerita Matematika (TSCM) dalam penelitian ini digunakan peneliti untuk mendeskripsikan peran fungsi eksekutif siswa SMP dalam menyelesaikan soal cerita ditinjau dari kemampuan matematika. Terdiri dari tiga soal yang berasal dari sebuah teks soal cerita seperti pada Gambar 2.

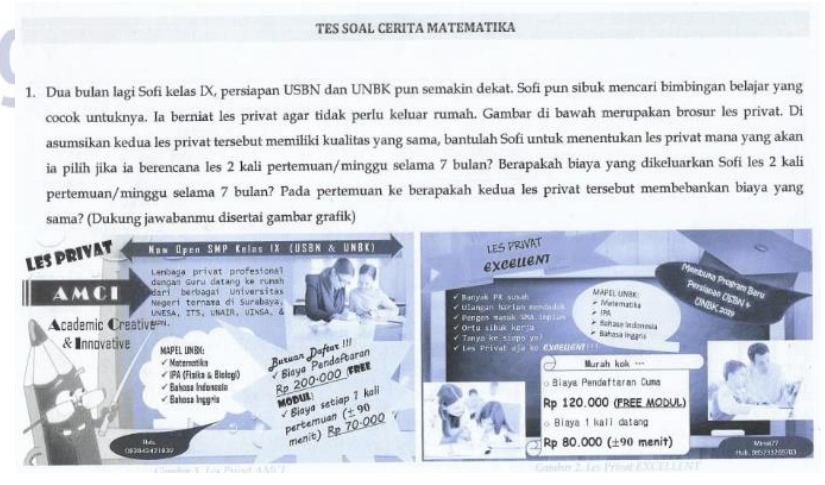

Gambar 2. Tes Soal Cerita Matematika (TSCM)

Selanjutnya setiap anak mengerjakan soal selama 40 menit. masing-masing anak memperoleh hasil yang 
berbeda. Hasil pekerjaan dari TKMR ditunjukkan pada Gambar 3 dan Gambar 4.
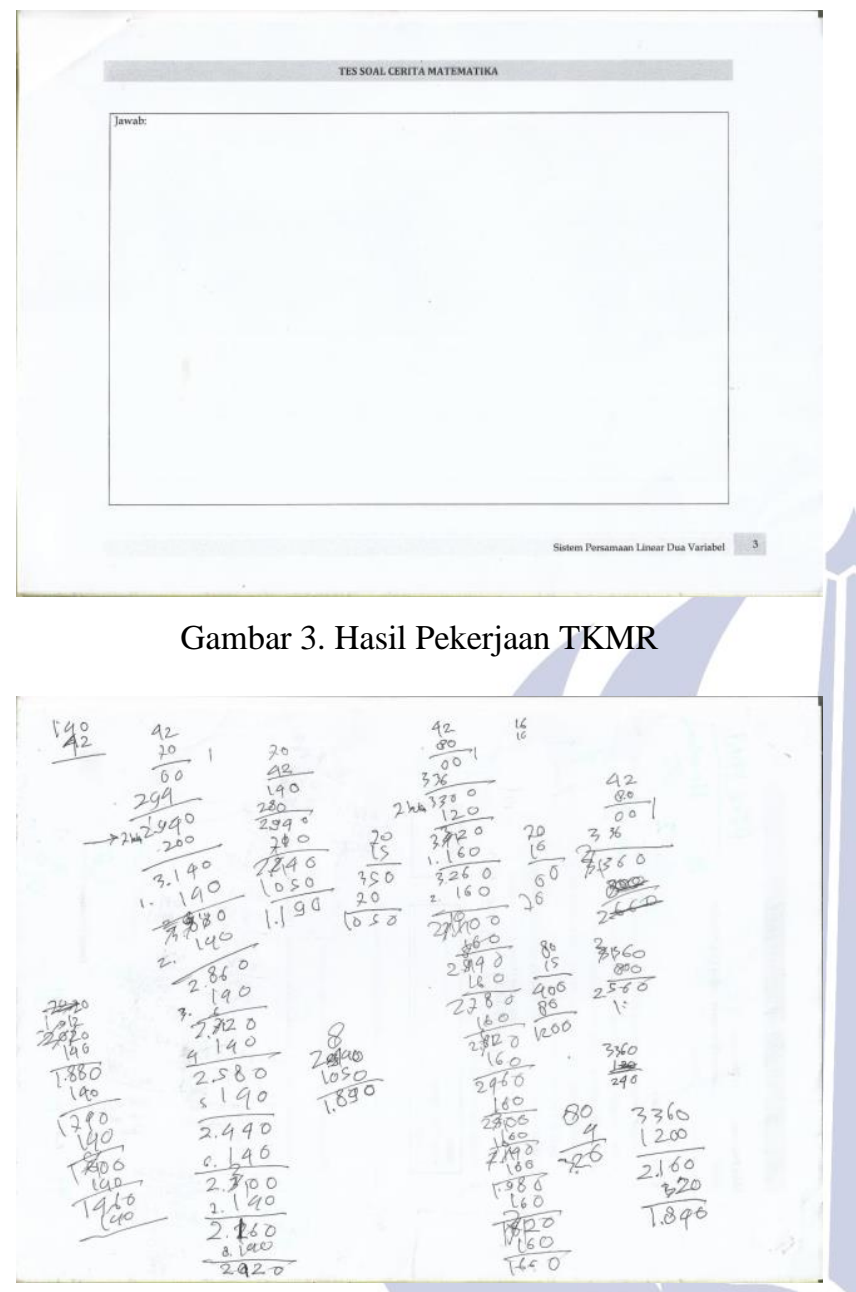

Gambar 4. Kertas Hitungan TKMR

Berdasarkan Gambar 3, diketahui bahwa TKMR sama sekali tidak bisa mengerjakan soal yang diberikan. Jika ditinjau dari kertas buram yang diberikan, diketahui bahwa TKMR hanya mencoba-coba perhitungan tanpa memiliki arah pekerjaan. Pekerjaan lebih terkesan mencoba-coba. Untuk memastikannya, peneliti melakukan wawancara untuk mengetahui proses TKMR dalam mengerjakan soal yang diberikan. Hasil wawancara antara peneliti (P) dengan TKMS adalah sebagai berikut.

$\mathrm{P} \quad$ : Apa yang pertama kali kamu ketahui tentang soal ini?

TKMR : Maksudnya?

$\mathrm{P} \quad$ : Oke pertanyaan sederhana saja, dalam satu bulan ada berapa Minggu?

TKMR : 3 Minggu

$\mathrm{P} \quad$ : Lalu ada pertemuan dalam 7 bulan?

TKMR : $3 \times 2 \times 7=42$ pertemuan

$\mathrm{P} \quad$ : Informasi apakah yang kamu dapatkan dalam memecahkan soal berikut?

TKMR : Ada dua tempat les. Les pertama pendaftaran Rp. 200.000 dengan biaya per pertemuan adalah Rp. 70.000 . Tempat les kedua pendaftaran Rp.
120.000 dengan biaya per pertemuan $\mathrm{Rp}$. 80.000

$\mathrm{P} \quad$ : Oke pertanyaan sederhana saja, dalam satu bulan ada berapa Minggu?

TKMR : 3 Minggu

$\mathrm{P} \quad$ : Lalu ada pertemuan dalam 7 bulan?

TKMR : $3 \times 2 \times 7=42$ pertemuan

$\mathrm{P} \quad$ : Apakah kamu memiliki pemodelan terkait penyelesaian soal ini?

TKMR : Tidak ada

$\mathrm{P} \quad$ : Apakah kamu memiliki rencana dalam penyelesaian soal ini? Jelaskan

TKMR : Iya ada. Yaitu dengan cara mengalikan 42 dengan harga tiap pertemuan di tempat les

$\mathrm{P} \quad$ : Apakah menurutmu itu sudah benar?

TKMR : Belum, karena saya tidak menemukan jawabannya. Saya tidak menemukan kapan mereka akan membayar dengan jumlah yang sama.

$\mathrm{P}$

: Apakah kamu memiliki cara yang lain untuk mengetahui kebenaran jawaban dari pekerjaan kamu?

TKMR : Ada, tapi saya tidak tahu

Berdasarkan hasil wawancara di atas, proses fungsi eksekutif remembering dan organizing pada TKMR tidak muncul, karena ia tidak ingat materi maupun cara menyelesaikan soal TSCM yang diberikan, sehingga ia tidak bisa mengorganisasi informasi yang relevan dan tidak relevan berdasarkan pengetahuan yang diperoleh. Untuk menuliskan apa yang diketahui dan ditanya pada soal, ia juga tidak menuliskannya secara rinci. Proses fungsi eksekutif selanjutnya yaitu shifting dan prioritizing, ketika peneliti bertanya apakah TKMR memiliki pemodelan terkait penyelesaian soal tersebut, ia menjawab tidak ada, namun ia memiliki rencana dalam menyelesaikan soal tersebut, dan melakukan rencana penyelesaiannya serta berusaha untuk menemukan jawabannya. Selanjutnya proses terakhir adalah checking, ketika peneliti bertanya tentang jawaban yang TKMR temukan dan meminta untuk mengecek serta memeriksa kembali ia merasa jawaban yang diperoleh belum benar karena ia tidak menemukan jawaban dari pertanyaan yang ada di TSCM dan ia juga tidak mengetahui cara penyelesaian lain untuk mendapatkan jawaban dari pertanyaan tersebut.

Selanjutnya hasil pekerjaan TKMS ditunjukkan pada Gambar 5 dan Gambar 6. 

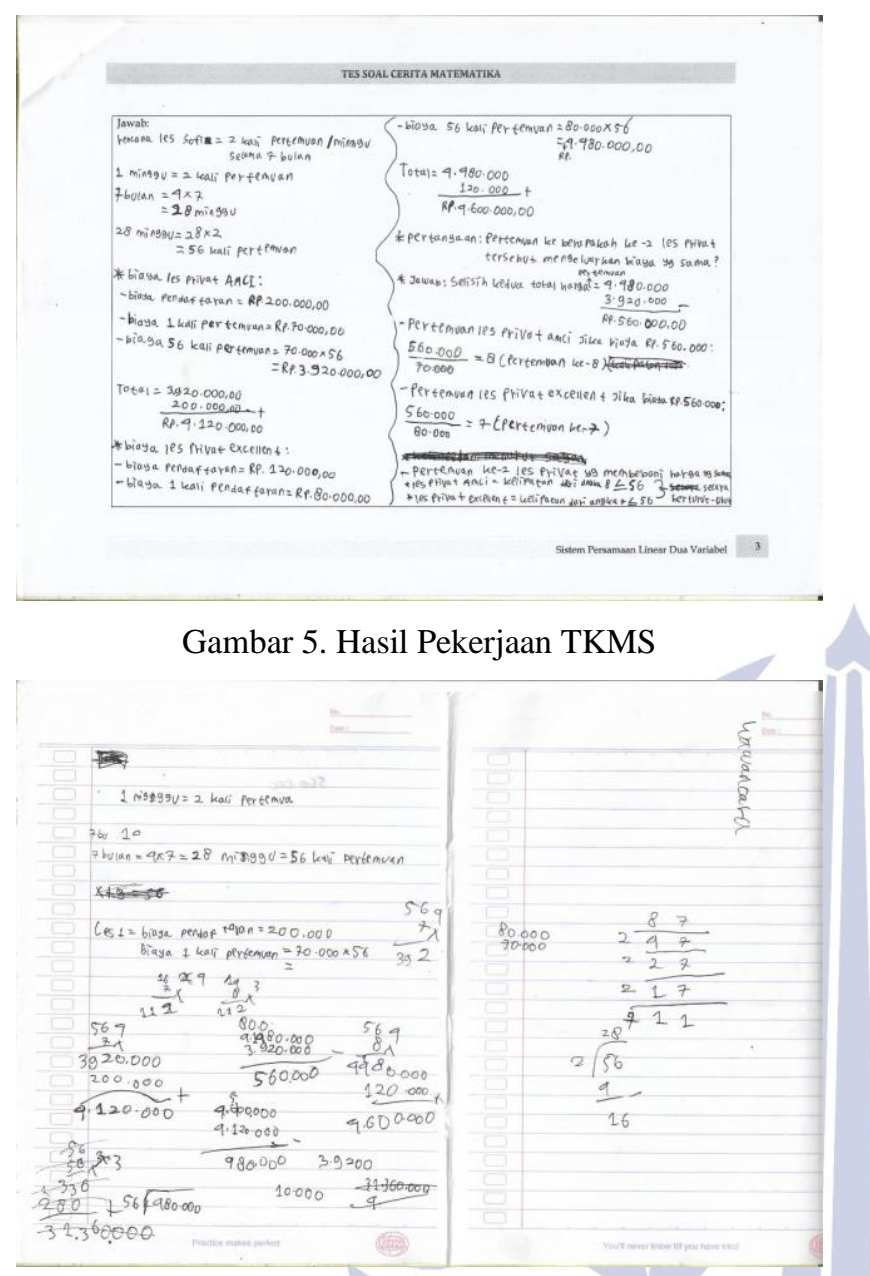

Gambar 6. Kertas Hitungan TKMS

Hasil pekerjaan dari TKMS diketahui sudah memiliki arah kepada jawaban yang benar. Namun masih ada beberapa konsep yang tidak tertulis. Jawaban dan coretan yang diperoleh dari anak dengan TKM sedang terkesan melompati sebuah konsep. Untuk memahami proses pengerjaannya, dilakukan wawancara dengan TKMS. Hasil wawancara antara peneliti (P) dengan TKMS adalah sebagai berikut.

P : Bagaimana cara kamu memahami soal ini?

TKMS : Saya sudah pernah belajar tentang ini. Namun saya tidak tahu nama materi ini

$\mathrm{P} \quad$ : Soal ini apa yang ditanyakan?

TKMS : Berapa biaya les AMCI dan EXCELLENT dan kapan biaya dua les privat tersebut sama. Serta tempat les mana yang harus dipilih Sofi

P : Jika tanpa menghitung, kira-kira kamu pilih yang mana?

TKMS : Les AMCI

P : Setelah dihitung, apakah jawabanmu sesuai dengan perhitungan?

TKMS : iya sesuai

P : Apakah kamu menggunakan konsep sesuai dengan materi yang diingat?
TKMS : Iya. Tapi saya lupa cara yang benar, hanya saya ingat pernah mengerjakan soal seperti ini

P : Apakah kamu bisa ketemu jawabannya sesuai dengan materi yang kamu ingat tadi?

TKMS : Tidak, saya tadi mencoba-coba saja.

$\mathrm{P} \quad$ : Bagaimana konsep yang kamu gunakan?

TKMS : Kita gunakan biaya pendaftaran ditambah dengan total pembayaran selama 7 bulan. Nanti akan diketahui les mana yang lebih mahal.

P : Apakah kamu sudah menemukan kapan pembayaran antara AMCI dan

\section{EXCELLENT sama?}

TKMS : Iya saya menemukan

P : Apakah kamu bisa menuangkannya dalam gambar?

TKMS : Tidak bisa. Saya perlu tambahan sekitar 60 menit waktu untuk menggambar

P : Apakah kamu ada inisiatif lain untuk bisa menggambar?

TKMS : Ada, tapi saya tidak tahu caranya. Saya harus tahu contohnya, baru bisa mengerjakan

$\mathrm{P}$

: Setelah melakukan perhitungan, apakah kamu yakin jawabanmu benar? Jelaskan

TKMS : Saya yakin, karena harga yang harus dibayarkan masih logis sesuai dengan pertemuan yang dilakukan

Berdasarkan hasil wawancara di atas, proses fungsi eksekutif yang pertama yaitu remembering. Pada proses ini TKMS ingat bahwa ia pernah belajar tentang materi ini namun ia tidak ingat apa nama materi pembelajarannya. Selain itu ia tidak tau strategi apa yang digunakan dalam menyelesaikan soal itu. Selanjutnya yaitu organizing, pada proses ini TKMS menggunakan informasi-informasi yang ia ingat untuk menyelesaikan soal tersebut dan ia menuliskan apa yang diketahui dan ditanya pada soal secara rinci. Proses fungsi eksekutif selanjutnya yaitu shifting dan prioritizing. Pada siswa TKMS kedua proses ini tidak muncul karena ia tidak merepresentasikan soal ke dalam model matematika dan tidak menentukan rencana penyelesaian masalah karena ia tidak tau strategi/ cara apa yang digunakan dalam menyelesaikan soal tersebut. Namun meskipun ia tidak ingat ttg stra strategi/ cara apa yang digunakan dalam menyelesaikan soal tersebut, ia tetap berusaha untuk mencari solusi dari pertanyaan tersebut yaitu dengan cara trial and error atau coba-coba dan ia bisa menjawab dengan benar 2 dari 3 soal yang diberikan. Proses fungsi eksekutif yang terakhir yaiu checking, dan proses ini muncul pada TKMS. Setelah ia menemukan 2 jawaban tersebut dan ia memeriksa serta berpikir apakah logis jawaban yang ia dapat maka ia yakin bahwa 2 dari 3 jawaban tersebut adalah benar. Sedangkan soal yang terakhir ia tidak yakin dan tidak tau lagi harus 
menggunakan strategi/ cara apa yang digunakan dalam menyelesaikan soal tersebut.

Hasil pekerjaan TKMT ditunjukkan pada Gambar 7 dan Gambar 8 .

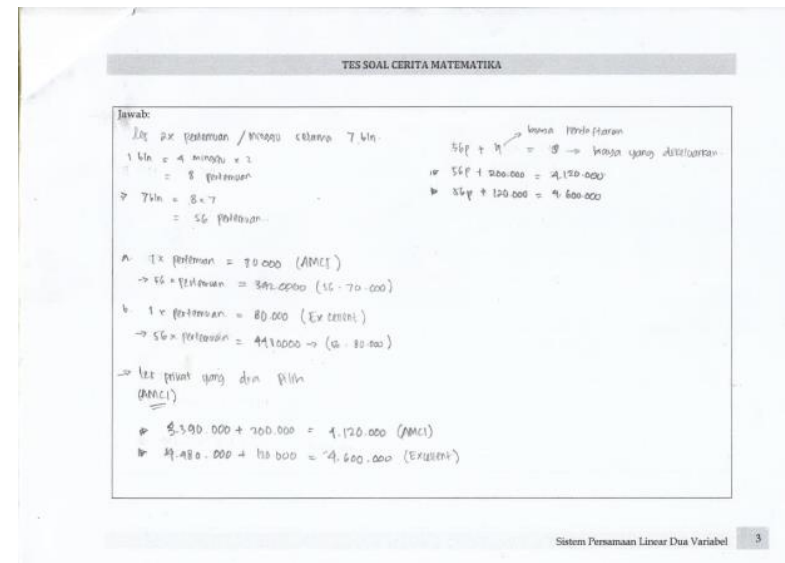

Gambar 7. Hasil Pekerjaan Anak dengan TKM Tinggi

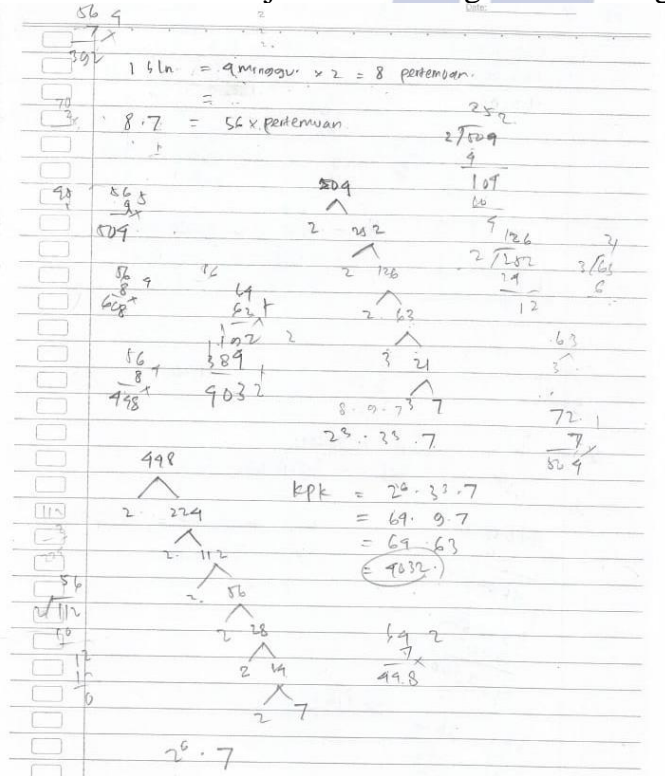

Gambar 8. Kertas Hitungan Anak dengan TKM Sedang

Hasil pekerjaan TMKT menunjukkan bahwa dia telah mampu mengerjakan dengan baik dua dari tiga soal yang diberikan. Pekerjaan selesai dengan baik, meskipun masih ada satu soal yang terlewat dalam pengerjaannya. Selanjutnya peneliti melakukan wawancara untuk mengetahui proses pengerjaan soal oleh TKMT. Berikut ini hasil wawancara peneliti dengan TKMT.

$\begin{array}{lll}\mathrm{P} & : & \text { Apa yang kamu pahami tentang soal } \\ \text { TKMT } & : & \text { Perbandingan dua les dengan biaya } \\ & \text { pendaftaran dan biaya harian yang } \\ & & \text { berbeda } \\ \mathrm{P} & : & \text { Apakah kamu tahu, ini tenteng materi } \\ & \text { apa? } \\ \text { TKMT } \quad: & \text { SPLDV } \\ \mathrm{P} & : & \text { Apakah kamu tahu cara } \\ & \text { menyelesaikannya? Dan apakah kamu } \\ & \text { menggunakannya seluruhnya? }\end{array}$

TKMT : Bisa dengan eliminasi dan substitusi. Tapi tidak saya gunakan seluruhnya P : Mengapa?

TKMT : Karena saya memodelkan dulu baru dikerjakan. Tapi tidak jadi karena saya masih ragu dan takut salah

P : Bagaimana kamu bisa Inge kalau itu SPLDV?

TKMT : Karena saya sering latihan soal-soal seperti ini di rumah

P : Bagaimana cara kamu mulai pekerjaan ini

TKMT : 56 pertemuan dikali biaya per bulan ditambah dengan biaya pendaftaran

P : Apakah kamu bisa menemukan titik temu dua les itu membayar dengan harga yang sama dengan substitusi atau eliminasi?

TKMT : Tidak, saya menggunakan KPK

$\mathrm{P} \quad$ : Bagaimana kamu menguji kebenaran jawabanmu?

TKMT : Dengan melihat jawaban. Jika jawaban logis, maka sudah benar

TKMS : Saya yakin, karena harga yang harus dibayarkan masih logis sesuai dengan pertemuan yang dilakukan

Berdasarkan hasil wawancara di atas, proses fungsi eksekutif yang pertama yaitu remembering. Pada proses ini TKMT ingat bahwa ia pernah belajar tentang materi ini serta ingat apa nama materi pembelajarannya. Selain itu juga tau strategi apa yang digunakan dalam menyelesaikan soal itu, yaitu dengan metode sustistusi dan eliminasi. Selanjutnya yaitu organizing, pada proses ini TKMT menggunakan informasi-informasi yang ia ingat untuk menyelesaikan soal tersebut dan mengeliminasi informasiinformasi yang tidak ia butuhkan dalam menyelesaikan soal tersebut, serta menuliskan apa yang diketahui dan ditanya pada soal secara rinci. Proses fungsi eksekutif selanjutnya yaitu shifting, dan proses tersebut tidak muncul karena TKMT tidak tau bagaimana cara memodelkan soal tersebut ke dalam bentuk matematika karena ia merasa tidak bisa dimodelkan dalam bentuk $x$ dan $y$. Namun ia telah menentukan rencana penyelesaian soal yang menurut ia tepat. Selanjutnya yaitu prioritizing. Pada proses ini TKMT melakukan rencana penyelesaian yang telah ia tentukan tadi, namun dipertengahan saat melaksanakan rencana penyelesaian, ia tidak mendapatkan jawaban dari soal terakhir yang ada pada TSCM dan ia segera mencari alternatif penyelesaian lain yaitu dengan cara menggunakan FPB dan KPK karena ia melihat terdapat kata "bersama-sama". Namun alternatif penyelesaian tersebut tidak berhasil menjawab soal yang terakhir. Proses fungsi eksekutif yang terakhir yaiu checking, dan proses ini muncul pada TKMT. Setelah ia menemukan 2 jawaban tersebut dan ia memeriksa serta berpikir apakah logis jawaban yang ia dapat maka ia yakin bahwa 2 dari 3 jawaban tersebut adalah benar. Sedangkan soal yang 
terakhir ia tidak yakin dan tidak tau lagi harus menggunakan strategi/ cara apa yang digunakan dalam menyelesaikan soal tersebut.

\section{Pembahasan}

Hasil penelitian menemukan bahwa fungsi eksekutif memiliki peran dalam menyelesaikan soal cerita. Indikatorindikator yang mengacu pada Roditi dan Steinberg (2007) terbukti mampu mengukur kemampuan penyelesaian soal cerita. Kemampuan matematika digunakan sebagai ukuran kemampuan untuk menyelesaikan soal cerita matematika. hasil berbeda ditemukan pada beberapa penelitian lain. Penelitian oleh Laily (2014) menyebutkan bahwa untuk menyelesaikan soal cerita diperlukan kemampuan untuk membaca dan memahami soal. Kemampuan membaca yang dimaksud adalah kemampuan membaca pemahaman. Kemampuan membaca pemahaman mempengaruhi kemampuan untuk menyelesaikan masalah matematika. Khasanah (2015) menambahkan bahwa selain kemampuan membaca dan memahami soal, diperlukan kemampuan untuk menceritakan kembali soal dengan menggunakan bahasa sendiri. Lebih lanjut, Karinaputri (2013) menjabarkan terkait kemampuan yang diperlukan dalam menyelesaikan soal cerita dalam matematika. Kemampuan yang diperlukan menurut Karinaputri meliputi kemampuan menentukan apa yang diketahui dari soal, kemampuan menentukan apa yang ditanyakan oleh soal, kemampuan menyelesaikan soal dengan membuat kalimat matematika, dan kemampuan menjawab soal dengan tepat.

Hasil pekerjaan siswa TKMR tidak diisi sama sekali. Sedangkan hasil pekerjaan TKMS dikerjakan meskipun belum selesai sepenuhnya. Namun ketika dilaksanakan wawancara, mereka menjabarkan pikiran mereka terkait soal yang diberikan. Peneliti menemukan bahwa siswa lebih mudah untuk menjabarkan jawaban secara langsung dibanding dalam bentuk tulisan. Hal ini sesuai dengan strategi menyelesaikan soal matematika oleh Burn (2004). Menurutnya siswa perlu untuk mengungkapkan jawaban mereka secara lisan dibanding secara tulisan. Jadi sebagai guru perlu juga untuk menanyakan kepada siswa terkait hasil pekerjaannya. Kemudian Burns juga memberikan saran untuk membuat soal yang mudah dipahami siswa. Hal ini kemudian sejalan dengan pernyataan dari Khasanah (2015) bahwa siswa perlu memiliki kemampuan dalam pemahaman membaca soal.

Hasil TSCM kepada seluruh subjek penelitian mendapatkan hasil yang seragam. Masing-masing siswa memiliki alasan terkait jawaban yang mereka berikan setelah TSCM selesai. Berikut akan dilakukan analisis terkait fungsi eksekutif yang berperan dalam penyelesaian soal cerita.

Memory
Indikator proses eksekutif memory seperti ditunjukkan pada Tabel 1 adalah mengingat pengetahuan yang diperoleh. Masing-masing subjek penelitian memiliki tingkat memory yang berbeda-beda. TKMR mengatakan bahwa dia sama sekali tidak ingat dengan materi yang digunakan dalam TSCM. Hasil perhitungannya juga tidak memiliki arah dan terkesan hitungan bebas. Kesalahan yang dilakukan oleh TKMR merupakan kesalahan pada aspek terapan matematika (Lestari, Noornia, \& Rahayu, 2010; Ningrum, 2013; Khasanah, 2015) TKMS memiliki ingatan bahwa dia pernah belajar materi dalam TSCM, namun tidak ingat nama materi yang digunakan. Ia bisa mengerjakan, namun konsep yang dia gunakan masih belum tepat. TKMT masih ingat betul materi dan konsep yang digunakan dalam TSCM. Dia bisa mengerjakan sesuai dengan konsep yang dimiliki. Dalam hal ini diketahui bahwa seseorang dengan tingkat kemampuan matematika tinggi memiliki fungsi eksekutif memory yang lebih baik.

Dalam soal cerita siswa akan dituntut untuk mampu memahami jenis materi apa yang harus digunakan dalam menyelesaikannya. Fungsi eksekutif memori memiliki peran penting dalam proses memanggil kembali materimateri yang pernah dipelajari sebelumnya. Setiap individu memiliki kemampuan dalam mengorganisasikan informasi dan belajar tentang kesadaran menggunakan kemampuan memorinya (Chairani, 2016). Dengan memahami jenis materi yang pernah dipelajari, maka siswa akan mampu memiliki konsep dan strategi penyelesaiannya.

Organizing

Indikator dari fungsi eksekutif organizing seperti ditunjukkan pada Tabel 1 adalah a) mengorganisasi informasi yang relevan dan tidak relevan berdasarkan pengetahuan yang diperoleh dan b) menuliskan apa yang diketahui dan ditanya. Berdasarkan hasil TSCM, seluruh subjek masih belum menuliskan data-data yang diketahui dalam soal cerita. Namun setelah dilakukan wawancara, seluruh subjek baik TKMR, TKMS, TKMT menjelaskan bahwa mereka telah mampu memahami tentang apa yang diketahui dan apa yang ditanyakan dalam soal. Meskipun mereka tidak merincikannya lebih lanjut ke dalam bentuk jawaban tertulis.

Kemampuan untuk menuliskan apa yang diketahui dan ditanyakan dalam soal penting untuk memilah data-data mana saja yang akan digunakan dan tidak. Dalam soal cerita, data-data yang nampak maupun tidak nampak penting untuk diketahui. Kehilangan satu data akan memberikan hasil yang tidak sesuai dengan jawaban yang seharusnya. Kemampuan untuk menerjemahkan masalah dan mengetahui maksud dari masalah yang diberikan merupakan satu dari tiga aspek penting dalam penyelesaian soal cerita (Khasanah, 2015). Hasil wawancara 
menemukan bahwa seluruh subjek telah memiliki fungsi eksekutif organizing yang baik.

\section{Shifting}

Shifting adalah kemampuan untuk membentuk soal cerita ke dalam model matematika dan merencanakan cara mengerjakannya. Fungsi eksekutif ini digunakan dalam penyelesaian soal cerita untuk memperkirakan jawaban soal cerita sebelum benar-benar mengerjakannya. Berdasarkan Tabel 1, indikator yang digunakan dalam proses shifting adalah a) merepresentasikan soal ke dalam model matematika dan b) menentukan rencana penyelesaian masalah.

Hasil wawancara dengan TKMR ditemukan bahwa dia telah memiliki perencanaan apa yang harus dilakukan. Namun di akhir perhitungan dia masih belum bisa menemukan jawaban yang benar. Jika dilihat pada pernyataan sebelumnya, TKMR memiliki kesalahan pada pemahaman konsep dasar. Sehingga dia menemukan perhitungan yang salah, meskipun telah memiliki rencana. TKMR belum mampu membuat sebuah model matematika dalam mengerjakan soal.

Sedikit berbeda dengan TKMR, TKMS telah memahami konsep dasar pengerjaan soal. Perencanaan yang dikerjakannya telah menemukan jawaban yang benar. Namun TKMS masih belum bisa membentuk model matematika dalam menyelesaikan soal cerita.

TKMT telah memiliki perencanaan yang baik dalam menyelesaikan soal cerita. Dia juga telah memiliki model matematika dalam menyelesaikan soal cerita. Dia mampu membentuk soal cerita ke dalam sebuah model matematika untuk diselesaikan. TKMT memiliki beberapa model penyelesaian soal cerita yang digunakan. Dalam hal ini penguasaan konsep dan memory memegang hal penting dalam proses shifting.

Kemampuan untuk merumuskan soal ke dalam model matematika adalah kemampuan tingkat tinggi dari penyelesaian masalah matematika. Seorang siswa dituntut untuk dapat menyelesaikan dan menggunakan aturanaturan yang telah dimiliki untuk menyusun sebuah rumusan atau model matematika (Alawiyah, 2014). Siswa perlu memiliki aspek ini karena digunakan untuk perencanaan penyelesaian masalah pada soal cerita (Khasanah, 2015).

\section{Prioritizing}

Diketahui seluruh subjek telah memiliki rencana penyelesaian masalah dalam soal cerita. Keseluruhan telah mampu melaksanakan perencanaan yang dibuat sebelumnya. Namun TKMR mengalami kendala dalam pelaksanaan rencana yang dibuat dikarenakan permasalahan pemahaman konsep dan memory. TKMS dan TKMT dapat melaksanakan perencanaan yang dibuat dengan jawaban yang benar.
Namun seluruh subjek masih belum bisa menemukan bentuk grafik dari soal cerita yang diberikan. TKMR mengalami permasalahan di dalam memory dan pemahaman soal sehingga tidak bisa memberikan jawaban sama sekali. TKMS telah mampu memberikan perencanaan yang benar, namun tidak memiliki model matematika untuk membuat grafik. TKMT telah memiliki model untuk menyelesaikan soal cerita. Namun bentuk model yang dimiliki masih belum bisa digunakan untuk membuat grafik.

Checking

Proses fungsi eksekutif checking menekankan kemampuan untuk melakukan pengujian terhadap kebenaran jawaban yang telah dikerjakan. Hasil wawancara kepada TKMR menunjukkan bahwa dia masih kebingungan terkait konsep yang digunakan. Sedangkan TMKS dan TMKT mempertimbangkan jawaban akhir berdasarkan konsep yang sebelumnya dipahami. TMKS dan TMKT menyatakan jawaban benar karena hasil akhir dari perhitungan masih logis dan sesuai dengan data awal yang diketahui.

\section{PENUTUP}

\section{Simpulan}

Berdasarkan hasil TKM, TSCM, dan wawancara terhadap tiga siswa yang menjadi subjek penelitian, diperoleh kesimpulan sebagai berikut.

1. Fungsi eksekutif memiliki peran penting dalam penyelesaian soal matematika. Siswa yang memiliki tingkat kemampuan matematika tinggi memiliki fungsi eksekutif yang baik. Hal ini dapat dilihat dari perbedaan pola berpikir dan menjawab soal cerita yang diberikan kepada masing-masing subjek penelitian.

2. TMKR cenderung sulit untuk bisa fokus dan memiliki daya ingat yang rendah. Selain itu TMKR masih belum bisa untuk melakukan representasi soal dalam bentuk matematika.

3. TMKS bisa memecahkan masalah yang diberikan, meskipun masih ada beberapa konsep yang terlupa. Siswa pada tingkatan ini masih bisa dikembangkan kemampuannya. Siswa sudah mampu melakukan representasi soal cerita ke dalam bentuk matematika, namun masih terdapat kekurangan dalam memory. Sehingga dia mengalami kesulitan dalam melaksanakan perencanaan penyelesaian masalah.

4. Siswa dengan TKM tinggi memiliki kemampuan dalam pemecahan masalah dengan baik. Dia memiliki memory yang kuat, mampu merepresentasikan soal ke dalam bentuk matematika, dan melaksanakan perencanaan penyelesaian masalah dengan baik. Meskipun dia masih memiliki kekurangan dalam mengembangkan pemahaman yang dimiliki kepada konsep-konsep baru. 
5. Seseorang yang memiliki TKM tinggi menguasai dengan baik proses dalam fungsi eksekutif. Penguasaan yang baik dalam proses fungsi eksekutif baik untuk digunakan dalam penyelesaian soal cerita.

6. Fungsi eksekutif seorang siswa memiliki peran penting dalam penyelesaian bentuk soal cerita.

\section{Saran}

Guru-guru yang mengalami permasalahan dalam mengajarkan bentuk soal cerita dapat mempertimbangkan untuk memahami fungsi eksekutif. Siswa yang memiliki fungsi eksekutif baik akan lebih mudah dalam memahami soal cerita. Siswa yang memiliki kemampuan matematika yang baik, memiliki fungsi eksekutif yang baik pula. Hal ini dapat pula dijadikan pertimbangan guru dalam mengajar soal cerita kepada anak-anak.

Guru dapat menggunakan tes kemampuan matematika untuk memetakan tingkat fungsi eksekutif dari siswa. Pemetaan ini perlu dilakukan untuk dapat melihat sejauh mana tingkatan siswa dalam pemahaman soal matematika. Sehingga penyusunan soal cerita akan lebih dapat disesuaikan dengan fungsi eksekutif dari siswa yang diajar.

\section{DAFTAR PUSTAKA}

Amir, M. F. (2015). Proses berpikir kritis siswa sekolah dasar dalam memecahkan masalah berbentuk soal cerita matematika berdasarkan gaya belajar. JURNAL MATH EDUCATOR NUSANTARA: Wahana Publikasi Karya Tulis Ilmiah di Bidang Pendidikan Matematika, 1(2).

Ariani, Y., \& Kenedi, A. K. (2018). Model Polya Dalam Peningkatan Hasil Belajar Matematika Pada Pembelajaran Soal Cerita Volume Di Sekolah Dasar. Jurnal Inspirasi Pendidikan, 8(2), 25-36.

Ansori, I. (2015). Diagnosis kesulitan siswa dalam pemecahan masalah soal cerita pada materi barisan dan deret serta alternative remidinya di SMAN 16 Surabaya. Surabaya: PPs Unesa.

Alawiyah, T. (2014). Pembelajaran untuk Meningkatkan Kemampuan Komunikasi dan Pemecahan Masalah Matematik. In Makalah Disajikan dalam Prosiding Seminar Nasional Pendidikan Matematika Program Pasca Sarjana STKIP Siliwangi Bandung (Vol. 1, pp. 180-187).

Burns, M. (2004). Writing in math. Educational Leadership, 62(2), 30-33.

Chairani, Z. (2016). Metakognisi siswa dalam pemecahan masalah matematika. Deepublish.

Cragg, L., \& Gilmore, C. (2014). Skills underlying mathematics: The role of executive function in the development of mathematics proficiency. Trends in neuroscience and education, 3(2), 63-68.
Farida, N. (2015). Analisis kesalahan siswa SMP kelas VIII dalam menyelesaikan masalah soal cerita matematika. AKSIOMA: Jurnal Program Studi Pendidikan Matematika, 4(2).

Kahar, M. S., \& Layn, M. R. (2017). Analisis kesalahan siswa dalam menyelesaikan soal cerita matematika. Jurnal Math Educator Nusantara: Wahana Publikasi Karya Tulis Ilmiah Di Bidang Pendidikan Matematika, 3(2), 95-102.

Karnasih, I. (2015). Analisis kesalahan Newman pada soal cerita matematis (Newmans error analysis in mathematical word problems). Jurnal Paradikma, 8(01), 37-51.

Kaprinaputri, A. P. (2013). Kemampuan Menyelesaikan Soal Cerita Matematika. Jurnal Ilmiah Visi, 8(1), 1015.

Khasanah, U. (2015). Kesulitan menyelesaikan soal cerita matematika pada siswa SMP. Prosiding Seminar Nasional Pendidikan Matematika UMS 2015

Kulman, D., \& Daley, J. (2016, July 13). Strategies to Improve Math Skills \& Executive Functions. Retrieved December 17, 2020, from https://learningworksforkids.com/2013/10/strategiesto-improve-math-skills-executive-functions/

Laily, I. F. (2014). Hubungan kemampuan membaca pemahaman dengan kemampuan memahami soal cerita matematika sekolah dasar. Eduma: Mathematics Education Learning and Teaching, 3(1).

Lestari, N. I., Noornia, A., \& Rahayu, W. (2010). Analisis Kemampuan Siswa SD dalam Menerjemahkan Soal Cerita ke dalam Model Matematika dan Penyelesaiannya. Jurnal Matematika, Aplikasi dan Pembelajarannya, 9(1), 22-34.

Logsdon, A. (2020, September 17). How to Help Children Who Have Problems With Executive Functioning. Retrieved December 17, 2020, from https://www.verywellfamily.com/executive-

functioning-2162084

Mulyani, M., \& Muhtadi, D. (2019). Analisis Kesalahan Siswa dalam Menyelesaikan Soal Trigonometri Tipe Higher Order Thinking Skill Ditinjau dari Gender. JPPM (Jurnal Penelitian dan Pembelajaran Matematika), 12(1), 1-16.

Ningrum, L. S. (2013). Analisis Kemampuan Siswa Menyelesaikan Soal Matematika dalam Bentuk Cerita Pokok Bahasan Barisan dan Deret pada Siswa Kelas XII SMA Al-Islam 3 Surakarta (Doctoral dissertation, Universitas Muhammadiyah Surakarta).

Novferma, N. (2016). Analisis kesulitan dan self-efficacy siswa SMP dalam pemecahan masalah matematika berbentuk soal cerita. Jurnal Riset Pendidikan Matematika, 3(1), 76-87. 
Raghubar, K. P., Barnes, M. A., \& Hecht, S. A. (2010). Working memory and mathematics: A review of developmental, individual difference, and cognitive approaches. Learning and individual differences, 20(2), 110-122.

Rahmania, L., \& Rahmawati, A. (2016). Analisis kesalahan siswa dalam menyelesaikan soal cerita persamaan linier satu variabel. JMPM: Jurnal Matematika dan Pendidikan Matematika, 1(2), 165174.

Roditi, B. N., \& Steinberg, J. O. A. N. (2007). The strategic math classroom. Executive function in education: From theory to practice, 237-260.

Rofiki, I. (2013). Profil Pemecahan Masalah Geometri Siswa Kelas Akselerasi SMP Negeri 1 Surabaya Ditinjau dari Tingkat Kemampuan Matematika. In Prosiding Seminar Nasional Matematika dan Aplikasinya Departemen Matematika Fakultas Sains dan Teknologi Universitas Airlangga (Vol. 1, pp. 300310).

Sukmadinata, N. S. (2011). Metode Penelitian Pendidikan. Bandung: PT. Remaja Rosdakarya.

Team, T. (2020, October 22). Understanding Executive Functioning Issues in Your Child. Retrieved December 17 , 2020, from https://www.understood.org/en/learning-thinkingdifferences/child-learning-disabilities/executivefunctioning-issues/understanding-executivefunctioning-issues-in-yourchild? ul=1\%2As5m0md\%2Adomain userid\%2AY W1wLWVOaHY3NkdZOEpWRTE0eG5PcFVzaEE. 